\title{
Review \\ Potential Role of Omega-3 Polyunsaturated Fatty Acids in Pediatric Food Allergy
}

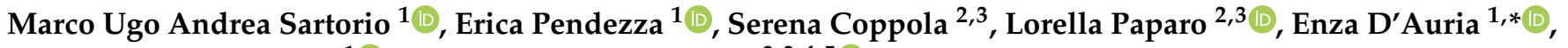 \\ Gian Vincenzo Zuccotti ${ }^{1}$ (D) and Roberto Berni Canani ${ }^{2,3,4,5}$ (i)
}

1 Department of Pediatrics, Vittore Buzzi Children's Hospital, University of Milan, 20154 Milan, Italy; marcoua.sartorio@gmail.com (M.U.A.S.); erica.pendezza@unimi.it (E.P.); gianvincenzo.zuccotti@unimi.it (G.V.Z.)

2 Department of Translational Medical Science-Pediatric Section, University of Naples "Federico II", 80131 Naples, Italy; sery.cop28@gmail.com (S.C.); paparolorella@gmail.com (L.P.); berni@unina.it (R.B.C.)

3 ImmunoNutrition Lab at CEINGE-Advanced Biotechnologies, University of Naples "Federico II", 80131 Naples, Italy

4 European Laboratory for the Investigation of Food-Induced Diseases, University of Naples "Federico II", 80131 Naples, Italy

5 Task Force on Microbiome Studies, University of Naples "Federico II", 80131 Naples, Italy

* Correspondence: enza.dauria@unimi.it

check for

updates

Citation: Sartorio, M.U.A.; Pendezza,

E.; Coppola, S.; Paparo, L.; D'Auria

E.; Zuccotti, G.V.; Berni Canani, R.

Potential Role of Omega-3

Polyunsaturated Fatty Acids in

Pediatric Food Allergy. Nutrients

2022, 14, 152. https://doi.org/

$10.3390 /$ nu14010152

Academic Editor:

Alessandra Bordoni

Received: 13 November 2021

Accepted: 24 December 2021

Published: 29 December 2021

Publisher's Note: MDPI stays neutral with regard to jurisdictional claims in published maps and institutional affiliations.

Copyright: (C) 2021 by the authors. Licensee MDPI, Basel, Switzerland. This article is an open access article distributed under the terms and conditions of the Creative Commons Attribution (CC BY) license (https:// creativecommons.org/licenses/by/ $4.0 /)$.

\begin{abstract}
Polyunsaturated fatty acids (PUFAs) are involved both in immune system regulation and inflammation. In particular, within the PUFAs category, omega-3 ( $\omega-3)$ may reduce inflammation, whereas omega-6 ( $\omega-6)$ PUFAs are generally considered to have a proinflammatory effect. Recent evidence highlights an imbalance in the $\omega-3: \omega-6$ ratio with an increased intake of $\omega-6$, as a consequence of the shift towards a westernized diet. In critical age groups such as infants, toddlers and young children, as well as pregnant and lactating women or fish allergic patients, $\omega-3$ intake may be inadequate. This review aims to discuss the potential beneficial effects of PUFAs on pediatric food allergy prevention and treatment, both at prenatal and postnatal ages. Data from preclinical studies with PUFAs supplementation show encouraging effects in suppressing allergic response. Clinical studies results are still conflicting about the best timing and dosages of supplementation and which individuals are most likely to benefit; therefore, it is still not possible to draw firm conclusions. With regard to food-allergic children, it is still debated whether PUFAs could slow disease progression or not, since consistent data are lacking. In conclusion, more data on the effects of $\omega-3$ PUFAs supplementation alone or in combination with other nutrients are warranted, both in the general and food allergic population.
\end{abstract}

Keywords: omega-3 polyunsaturated fatty acids; food allergy; immune system; allergy prevention; nutritional sciences; pediatrics

\section{Introduction}

Polyunsaturated fatty acids (PUFAs) are a group of fatty acids with a molecular structure characterized by more than one double bond.

The two main families of PUFAs are the omega-3 ( $\omega-3)$ and omega- $6(\omega-6)$ families, which differ in the position of the first double bond [1]. The precursors of these families are linolenic acid (ALA; 18:3w-3) and linoleic acid (LA; 18:2w-6), respectively [2]. Linolenic acid and LA are defined as essential fatty acids since they cannot be synthesized by humans, so they must be obtained necessarily from the diet [2]. Evidence suggests that PUFAs may contribute both to immune system regulation and allergy development. PUFAs are involved, for instance, into cell membrane fluidity modification, production of inflammatory and anti-inflammatory mediators, and can also affect gene expression. Within the PUFAs category, $\omega-3$ may reduce inflammation and improve allergic symptoms [3], whereas $\omega-6$ 
PUFAs are generally considered to have a proinflammatory effect since they favour Thelper cell 2 (Th-2) immune response and allergy development [4].

Over the last decades it has been observed that dietary changes, with a shift towards a "westernized" diet, have led to a general imbalance between the amount of $\omega-3$ and $\omega-6$ consumed in favour of $\omega-6$ PUFAs [1]. The western diet is characterized by a high dietary ratio of $\omega-6: \omega-3$ PUFAs, which are derived from increased fat and vegetable oils (including soybean, corn, sunflower, safflower oil, cotton seed oils) containing proinflammatory $\omega-6$ PUFAs, and reduced fiber, potentially contributing to allergic sensitization and to severity of allergic symptoms [5-7]. While the typical Western diet has a much greater ratio of $\omega-6$ PUFAs compared with $\omega-3$ PUFAs, research has shown that increasing the ratio of $\omega-3$ to $\omega-6$ fatty acids in the diet may decrease the incidence of many immune-mediated chronic conditions, including food allergy (FA).

Allergic diseases in infancy may present as a continuum where they progress from one to another in the so-called "atopic march" [8]. Classically, the atopic march begins with atopic dermatitis and then progresses to food allergy and respiratory allergy, including rhinitis and asthma. It is known that atopic dermatitis correlates with the risk of developing FA [9]. This could be due to the transcutaneous sensitization to food allergens via an inflamed and disrupted skin, according to the hypothesis of dual-allergen exposure, which suggests that allergic sensitization to food occurs through low-dose cutaneous sensitization, whereas early consumption of food protein induces oral tolerance [10].

Thus, the ability of $\omega-3$ PUFAs to prevent or reduce skin inflammation might also exert a protective role on food allergy cutaneous sensitization [11], contrasting the progression of the atopic march. To date, literature about the potential preventive role of $\omega$-3 PUFAs supplementation on atopic diseases is still scarce, and existing trials mostly focused on atopic dermatitis or wheezing rather than food allergy, an issue which needs to be further investigated.

The present review aims to focus on the potential role of $\omega-3$ polyunsaturated fatty acids in food allergy prevention and treatment; however, as many studies considered multiple allergic outcomes, including food allergy development, these studies have been included and are discussed. Knowledge gaps are also addressed. A comprehensive search was conducted using the electronic databases MEDLINE via PubMed (www.pubmed.gov, accessed on 19 July 2021) and Embase databases (www.embase.com, accessed on 19 July 2021).

The following keywords were used: $\omega-3$ polyunsaturated fatty acids, $\omega-6$ polyunsaturated fatty acids, polyunsaturated fatty acids, eicosapentaenoic acid, docosahexaenoic acid, food allergy, immune system, allergy prevention, allergy treatment, children, pediatric food allergy, pregnancy PUFAs supplementation, lactation PUFAs supplementation, children PUFAs supplementation, human milk.

\section{2. $\omega$-3 PUFAs: Sources, Metabolism, and Recommended Intake}

The main sources of ALA are linseeds, chia seeds, vegetable oils such as linseed, soybean, rapeseed and wheat germ oils, and walnuts [2,12]. Linoleic acid is found mostly in vegetable oils such as soybean, sunflower, corn seed, wheat germ and sesame oils [2,12]. Sources of arachidonic acid (AA) are meat and meat products, egg yolks and offal [2]. Eicosapentaenoic acid (EPA) and docosahexaenoic acid (DHA) are present in most fish and seafood products, and especially in oily fish and fish oil (Table 1). 
Table 1. Eicosapentaenoic acid (EPA) and docosahexaenoic acid (DHA) content in different fish species [13].

\begin{tabular}{ll}
\hline EPA $(\mathbf{g} / \mathbf{1 0 0} \mathbf{g})$ & DHA $(\mathrm{g} / \mathbf{1 0 0} \mathrm{g})$ \\
\hline Herring $1.09 \mathrm{~g}$ & Tuna $2.15 \mathrm{~g}$ \\
Salmon $0.89 \mathrm{~g}$ & Grouper $1.45 \mathrm{~g}$ \\
Tuna $0.80 \mathrm{~g}$ & Mackerel $1.26 \mathrm{~g}$ \\
Grey mullet $0.76 \mathrm{~g}$ & Salmon $1.19 \mathrm{~g}$ \\
Mackerel $0.73 \mathrm{~g}$ & Sardines $1.16 \mathrm{~g}$ \\
& Herring $1.01 \mathrm{~g}$ \\
& Swordfish $0.56 \mathrm{~g}$ \\
\hline
\end{tabular}

After ingestion, ALA and LA are metabolized in the liver by desaturases (5 and 6) and elongase to obtain long chain PUFAs: EPA, docosapentaenoic acid (DPA) and DHA from ALA in the $\omega-3$ group, and AA from LA in the $\omega-6$ group $[1,14]$. Since the $\omega-3$ and $\omega-6$ metabolic pathways share the same elongation and desaturation enzymes, they compete for conversion [1]. PUFAs also act as precursors to several bioactive metabolites, such as eicosanoids, including prostaglandins, leukotrienes and thromboxanes [14].

In Table 2 the Dietary reference values (DRVs) for PUFAs provided by the European Food Safety Authority (EFSA)'s Panel on Dietetic Products, Nutrition and Allergies are reported [15].

Table 2. Recommended polyunsaturated fatty acids (PUFAs) daily dose.

\begin{tabular}{|c|c|c|c|}
\hline & & AI & $\mathbf{R I}$ \\
\hline \multirow{4}{*}{$\begin{array}{l}\text { Infants } \\
\text { (6-12 months) }\end{array}$} & PUFAs & - & \\
\hline & $\omega-6$ PUFAs & - & \\
\hline & $\omega-3$ PUFAs (total) & - & \\
\hline & EPA-DHA & $\begin{array}{l}\text { DHA } 100 \mathrm{mg} / \text { day } \\
\text { from } 7 \text { months }\end{array}$ & \\
\hline \multirow{4}{*}{$\begin{array}{l}\text { Children and } \\
\text { adolescents } \\
(1-17 \text { years })\end{array}$} & PUFAs & - & \\
\hline & $\omega-6$ PUFAs & - & \\
\hline & $\omega-3$ PUFAs (total) & $\begin{array}{l}\text { Total: - } \\
\text { ALA: } 0.5 \% \text { En (from } \\
2 \text { years) }\end{array}$ & \\
\hline & EPA-DHA & $\begin{array}{l}\text { DHA } \\
100 \mathrm{mg} / \text { day until } \\
2 \text { years } \\
\text { EPA + DHA } \\
250 \mathrm{mg} / \text { day from } \\
2 \text { years }\end{array}$ & \\
\hline \multirow{4}{*}{$\begin{array}{l}\text { Pregnant and } \\
\text { lactating women }\end{array}$} & PUFAs & - & \\
\hline & $\omega-6$ PUFAs & - & \\
\hline & $\omega-3$ PUFAs (total) & $\begin{array}{l}\text { Total: - } \\
\text { ALA: } 0.5 \% \text { En }\end{array}$ & \\
\hline & & & $\begin{array}{l}\mathrm{EPA}+\mathrm{DHA} 250 \mathrm{mg} / \text { day } \\
+ \text { DHA 100-200 mg/day }\end{array}$ \\
\hline
\end{tabular}

Abbreviations: AI: Adequate Intake. RI: Reference Intake. En: total energy.

Data regarding PUFAs intake are rather far from recommendations. A systematic review recently assessed the intake of $\omega-3$ and $\omega-6$ PUFAs in specific population groups, including pregnant and lactating women, infants (aged 6 to 12 months) and children, from 17 different European countries. Results were compared to the EFSA recommendations. The results indicated that intakes of $\omega-3$ and $\omega-6$ PUFAs were largely suboptimal in specific 
population groups in Europe [16]. This is especially significant in critical age groups that have a higher requirement for these fatty acids and are therefore exposed to an increased risk of inadequate intake; among these groups are infants, toddlers, and young children, as well as pregnant and lactating women.

\section{3. w-3 PUFAs in Human Milk}

The composition of human milk differs among lactating women. These differences can be particularly relevant for the concentration of fatty acids [17]. ALA and LA are the main PUFAs present in human milk. Analysing human milk PUFAs content in nine European countries, a content of $0.9 \% \mathrm{wt} / \mathrm{wt}$ for ALA and $11.0 \% \mathrm{wt} / \mathrm{wt}$ for LA [18] was found.

A meta-analysis reviewing 65 studies reporting data from 2400 women worldwide indicated a mean concentration of DHA in human milk of $0.32 \pm 0.22 \%$ of total fatty acids, with a range from 0.06 to $1.4 \%$. Higher DHA concentrations were found in populations living near the sea and were associated with the consumption of fish and seafood [19]. A recent review by the European Academy of Allergy and Clinical Immunology (EAACI) addressing food allergy prevention suggested that breastfeeding may not exert a protective role on FA development; however, the evidence is small since only seven observational studies were included in the revision. Despite this, since human milk provides all of the nutritional needs of infants up to six months of age, EAACI recommends healthcare professionals to encourage breastfeeding [20,21].

\section{PUFAs Dietary Intake in Healthy and Allergic Children}

Proper timing for the introduction of fish, the main source of PUFAs, in infant diets remains debated: early introduction (before 9 months of life) may increase diet diversity and have potential beneficial effects. An increased diet variety during the first year of life may provide an increased amount of healthy nutrients and may also play a protective role in allergy development. Allergy prevention may be linked to early exposure to food allergens during immune system development but can also be related to early exposure to those nutrients which exert an immune modulating effect and prevent allergic sensitization. It has been demonstrated that the introduction of each additional food at 6 months of age reduced the risk of developing FA over the first 10 years of life [22]. These results suggest that diet diversity is associated with increased nutrient intake, including those nutrients which could have a protective role in allergy development, in particular $\omega-3$ fatty acids and nondigestible fibers $[23,24]$.

The American Academy of Paediatric Guidelines on timing of introduction of allergenic complementary foods states that delaying the introduction of allergenic foods such as fish beyond 4 to 6 months does not prevent atopic disease [25]. As fish represent the main source of $\omega-3$, introduction is recommended during the second semester of life with a variability depending on child development, family believers and socio-cultural factors [26].

Aldámiz-Echevarría et al. showed that food-allergic children on an elimination diet are at risk of developing $\omega-3$ PUFAs deficiency [27]. Since fish are the most relevant PUFAs source, allergy to fish may obviously lead to inadequate intake of $\omega$-3 PUFAs in children [26]. However, being allergic to one fish does not necessarily mean being allergic to all fish species [28]. For this reason, if the clinical history and/or the presence of specific $\operatorname{IgE}$ (sIgE) to one or more fish suggest the suspicious of FA, it is mandatory to perform an oral food challenge to confirm or to exclude an allergic reaction. Children who are allowed to consume at least two portions of fish per week reach an adequate amount of EPA and DHA [13].

In contrast, children who are not permitted to eat any type of fish should be supplemented with algal-derived $\omega-3$ fatty acids [29,30].

Similarly, supplementation is recommended in children who follow a vegetarian or vegan diet, as this dietary pattern implies the exclusion of animal-derived proteins, including fish, resulting in a reduced or null $\omega-3$ intake. 
Noteworthy is that a recent trial (2020) by Ogrodowczyk and colleagues investigated the associations between maternal dietary pattern and immunological markers (such as specific IgE profile and cytokines) in the offspring. A vegetarian/vegan diet was characterized by "prevalence of vegetables, fruits, juices, dark rice, and meat substitutes based on pulses, nuts, grains and herbs", together with a consistent elimination of animal products from the diet. The authors found that this dietary pattern seemed to be associated with high levels of total and specific IgE to several foods (cows' milk proteins, eggs, soybean, nuts, beef) and higher levels of interleukins in the offspring. One possible explanation is that early exposure to phytoestrogens can increase IgE production later.

However, as the same authors concluded, this association might be due to multiple confounding factors such as infant feeding type and birth method; therefore, additional studies are needed to draw firm conclusions [31].

\section{Role of $\omega-3$ PUFAs in the Regulation of Immune System Development and Function}

A large subset of cells and cytokines are involved in immune system development and function. Among them, CD4+ helper T (Th) cells are immune cells able to differentiate into different subgroups including Th1 and Th-2 cells, which play important roles in immunity by different patterns of cytokines secretion. Th1 cells stimulate the cellular immune response and favor IgM and IgG1 production by B cells, while Th-2 cells through cytokines production (IL4, IL5, IL13) are associated with IgE production and eosinophilic and mast cell recruitment resulting in allergic inflammation. The balance between $\omega-3$ and $\omega-6$ PUFAs is involved in the subject's propensity to develop allergic inflammation [32]. Th-2 inflammatory response promotes eosinophil chemotaxis and activation and IgE production by B lymphocytes.

During the period of immune programming, diet, environmental factors, microbiome and epigenetic mechanisms may play an important role in the development of FA [33].

\section{PUFAs Supplementation for Food Allergy Prevention: Preclinical Findings}

Several preclinical studies have indicated $\omega-3$ PUFAs as protective molecules against allergic inflammation [34-38]. In a murine model of allergy, DHA inhalation during the allergen challenge phase in mice suppressed airway eosinophilic inflammation, and this was accompanied by reduced numbers of inflammatory cells in bronchoalveolar lavage fluid and decreased airway hyperresponsiveness, and mucus production [38]. The new monoglyceride DHA derivative (CRBM-0244) and EPA derivative (EPA-MAG) showed preventive effects on airway eosinophilic inflammation, airway hyperresponsiveness and inflammatory cytokine production in OVA-induced asthmatic responses [36,37]. In mice with orally induced hen's egg allergy, feeding with $13 \%$ salmon oil diet containing $6.1 \%$ EPA and 7.5\% DHA partially prevented development of FA [39], although no differences in immunoglobulin levels were observed. Other studies in an animal model of FA reported that DHA and EPA were able to prevent and reduce cow's milk and peanut allergies [40] by reducing IgE, IgG1, and IgG2a levels and increasing Treg number, while lowering both Th-2 and Th1 activation [41].

An increased dietary $\omega-6 / \omega-3$ PUFAs ratio may induce a shift in the Th1/Th-2 balance towards a Th- 2 response [42]. It has been demonstrated that the ratio of IFN- $\gamma /$ IL-4 production by human peripheral blood mononuclear cells was significantly higher during consumption of $\omega-3$ PUFAs compared to a $\omega-6$ PUFAs-rich diet, as a result of reduced IL-4 secretion [42]. The protective effects of DHA against allergic disease is due, at least in part, to its capacity to reduce IgE production by human B cells [43], to suppress Th-2 polarizing and to enhance IL-10 production, with an increase of dendritic cell (DC) number [42,44].

The protective effect of $\omega-3$ PUFAs during the allergic sensitization phase is not only limited to their ability to antagonize antigen presentation to naive T-cells but also to a reduction of DC immunogenicity. In vitro studies by Zeyda et al. demonstrated that PUFAs administration to monocyte-derived DCs may block immunogenic function, causing an altered DC surface molecule expression and a reduction of cytokine release [45]. Similar 
results from Kong et al. showed that exposure of bone marrow-derived DC to DHA resulted in prolongation of immature phenotype and significant decrease of proinflammatory cytokine production and release [46]. Immature DC triggers a lower immune response together with a pattern of cytokine secretion, which induce a more tolerogenic state [47].

DHA and EPA modulate allergic inflammation by binding to several receptors, such as GPR120 and nuclear receptor PPAR $\alpha / \gamma$ [48] and inhibit MHC-II expression, activation of CD86 through TLR4, expression of costimulatory molecules (CD40, CD80, and CD86) and inflammatory cytokine production (IL-6 and IL-12p70) in DCs [49]. Interestingly, T-cells cocultured with DHA-treated murine DCs expressed higher expression of transforming growth factor (TGF) $\beta$ and forkhead box P3 (Foxp3) [46]. The stimulation of DCs with DHA significantly decreased the expression of DC surface marker OX40L, as well as the IL-12p40, IL-23 cytokine production and Th-2-type IL-13 response by DCs [50]. The effective DHA concentrations able to elicit these biological effects range from 2 to $100 \mu \mathrm{M}$ [51-54].

PUFAs metabolism involves the desaturases enzymes, $\Delta-5$ and $\Delta-6$ desaturases, encoded by FADS1 and FADS2 genes, respectively, localized on chromosome 11q12-13.1 [55]. Previous studies have studied the correlation between the genetic variants in the FADS gene cluster and PUFAs serum levels [56-62]. Polymorphisms in FADS2 were found negatively associated with activity of $\Delta-6$ desaturase and EPA production [63]. A study demonstrated the association between a reduced activity of $\Delta-6$ desaturase, the presence of FADS2 polymorphisms and lower PUFAs serum levels in subjects at 13 years of age [64], although the evidence on correlation between the FADS polymorphisms and FA is still controversial $[56,61,64]$. Increasing evidence suggests that genetic variation in fatty acid desaturase (FADS) genes influence the biological PUFAs status and the effect of dietary intake on PUFAs concentrations [65]. Given the impact of FADS genotype on PUFAs concentrations, it is likely that the genotype has the potential to influence health outcomes. This issue has been investigated in relation to different health outcomes, including allergic diseases, in particular asthma and eczema, with no conclusive results $[61,65,66]$. To our best knowledge, no studies have specifically investigated the effect of genetic variations on development of food allergies. The role of genetic variation on child health outcomes, including food allergies, needs to be further investigated, taking into account FADS genotype of both mother and child, as well as maternal and child FAD status.

\section{PUFAs Supplementation during Pregnancy and Breastfeeding for Allergy Prevention: Clinical Studies}

The prenatal period is a sensitive time, during which intrauterine exposures can modulate the course of development and confer an enduring effect on the offspring [66]. Since immune system development in early life is not yet complete, it can be modulated from environmental factors such as maternal diet [67]. Despite the inconclusive and conflicting results, several studies and meta-analyses investigated the role of $\omega-3$ PUFAs supplementation in pregnancy on offspring allergy [68-74]. Table 3 shows the clinical evidence on $\omega-3$ PUFAs supplementation and the occurrence of FA or food allergens sensitization. 
Table 3. Clinical evidence on $\omega-3$ PUFAs supplementation and the occurrence of FA or food allergens sensitization.

\begin{tabular}{|c|c|c|c|c|c|}
\hline Reference & $\begin{array}{l}\text { Subjects and } \\
\text { Number }\end{array}$ & Supplementation & Time & Outcome & Results \\
\hline $\begin{array}{l}\text { Dunstan JA, et al. } \\
\text { J Allergy Clin } \\
\text { Immunol. } 2003 \\
\text { [75] }\end{array}$ & $\begin{array}{l}40 \text { atopic } \\
\text { pregnant women }\end{array}$ & $\begin{array}{l}\text { Fish oil group: } 4 \text { (1-g) } \\
\text { fish oil capsules per } \\
\text { day comprising a total } \\
\text { of } 3.7 \mathrm{~g} \text { of } \omega-3 \text { PUFAs } \\
\text { with } 56.0 \% \text { as DHA } \\
\text { and } 27.7 \% \text { as EPA. } \\
\text { Control group: } 4 \text { (1-g) } \\
\text { capsules of olive oil } \\
\text { per day (containing } \\
66.6 \% \mathrm{n}-9 \text { oleic acid } \\
\text { and }<1 \% \omega-3 \text { PUFAs) }\end{array}$ & $\begin{array}{l}\text { From } 20 \text { weeks } \\
\text { gestation until } \\
\text { delivery }\end{array}$ & $\begin{array}{l}\text { Neonatal PUFAs } \\
\text { levels and } \\
\text { immunologic } \\
\text { response to } \\
\text { allergens at birth } \\
\text { and clinical } \\
\text { evaluation at } \\
12 \text { months of age } \\
\text { as a secondary } \\
\text { outcome }\end{array}$ & $\begin{array}{l}\text { All neonatal } \\
\text { cytokine responses } \\
\text { to all allergens } \\
\text { tended to be lower } \\
\text { in the fish oil } \\
\text { group; infants in } \\
\text { the fish oil group } \\
\text { were three times } \\
\text { less likely to be } \\
\text { sensitized to egg } \\
\text { allergen at } 1 \text { year } \\
\text { of age }\end{array}$ \\
\hline
\end{tabular}

145 pregnant women, affected

Furuhjelm C, et al. Acta

Paediatr. 2009 [68] by allergy themselves or having a husband or previous child with allergies
Daily supplementation with either $1.6 \mathrm{~g}$ EPA and $1.1 \mathrm{~g}$ DHA or placebo
From the 25(th) gestational week to average 3-4 months of breastfeeding
The incidence of allergic disease in the first year of infants' life
Reduction of the FA risk and IgE-associated eczema during the first year of life
Manley BJ, et al. Pediatrics. 2011 [76]
657 breastfed preterm infants (<33 weeks' gestation)
Mothers taking either tuna oil (high-DHA diet, $\sim 1 \%$ total fatty acids) or soy oil (standard-DHA, $\sim 0.3 \%$ total fatty acids) capsules
Incidence of bronchopulmonary dysplasia and parental reporting of atopic

rrom 2-4 days of postnatal age unti 40 weeks postmenstrual age conditions over the first 18 months of life
145 pregnant women, affected

Furuhjelm C, et al. PediatrAllergyImmunol. 2011 [77] by allergy themselves or having a husband or previous child with allergies
Daily supplementation with either $1.6 \mathrm{~g}$ EPA and $1.1 \mathrm{~g}$ DHA or placebo
From the 25(th) gestational week to average 3-4 months of breastfeeding
IgE-associated diseases last up to 2 years of age and assess the relationship between plasma proportions of $\omega-3$ PUFAs and the frequency and severity of infant allergic disease
No effect on the incidence of parental reported FA

\section{Decrease in} cumulative incidence of IgE-associated disease; high proportions of DHA and EPA in maternal and infant plasma phospholipids were associated with less IgE-associated disease and a reduced severity of the allergic phenotype

No reduction in the overall incidence of $\operatorname{IgE}$ associated allergies; lower atopic eczema and egg sensitisation 
Table 3. Cont.

\begin{tabular}{|c|c|c|c|c|c|}
\hline Reference & $\begin{array}{l}\text { Subjects and } \\
\text { Number }\end{array}$ & Supplementation & Time & Outcome & Results \\
\hline $\begin{array}{l}\text { D'Vaz N, et al. } \\
\text { Pediatrics. } 2012 \\
{[78]}\end{array}$ & $\begin{array}{l}420 \text { infants at } \\
\text { high atopic risk }\end{array}$ & $\begin{array}{l}\text { Daily supplement of } \\
\text { fish oil containing } \\
280 \mathrm{mg} \text { DHA and } \\
110 \mathrm{mg} \text { EPA or a } \\
\text { control (olive oil) }\end{array}$ & $\begin{array}{l}\text { From birth to age } \\
6 \text { months }\end{array}$ & $\begin{array}{l}\text { Occurrence of } \\
\text { allergic outcomes } \\
\text { including } \\
\text { sensitization, } \\
\text { eczema, asthma, or } \\
\text { FA }\end{array}$ & $\begin{array}{l}\text { No effects in the } \\
\text { prevention of } \\
\text { childhood allergic } \\
\text { disease }\end{array}$ \\
\hline $\begin{array}{l}\text { Best KP, et al. } \\
\text { World Allergy } \\
\text { Organ J. } 2018 \\
\text { [79] }\end{array}$ & $\begin{array}{l}706 \text { pregnant } \\
\text { women with a } \\
\text { fetus at high risk } \\
\text { of allergic } \\
\text { disease }\end{array}$ & $\begin{array}{l}\text { Fish oil capsules } \\
\text { (providing } 900 \mathrm{mg} \text { of } \\
\omega-3 \text { PUFAs daily) or } \\
\text { matched vegetable oil } \\
\text { capsules without } \omega-3 \\
\text { PUFAs (control group) }\end{array}$ & $\begin{array}{l}\text { From } 21 \text { weeks } \\
\text { gestation until } \\
\text { delivery }\end{array}$ & $\begin{array}{l}\text { IgE associated } \\
\text { allergic disease } \\
\text { (eczema or FA with } \\
\text { sensitisation) at } 3 \\
\text { and } 6 \text { years of age }\end{array}$ & $\begin{array}{l}\text { No significant } \\
\text { effects on } \\
\text { IgE-mediated } \\
\text { allergic disease } \\
\text { symptoms or } \\
\text { sensitization }\end{array}$ \\
\hline
\end{tabular}

Maternal supplementation in the DOMinO trial with $900 \mathrm{mg}$ of $\omega-3$ PUFAs, starting from 21 weeks of gestation until delivery, did not protect offspring against food allergen sensitization or allergy, although egg sensitization was lower than offspring of the control group (received matched vegetable oil capsules without $\omega-3$ PUFAs) $[69,79]$. Similarly, hen's egg sensitization through the skin prick test was reduced by more than $50 \%$ in infants of women who received fish oil (3.7 $\mathrm{g} \omega-3$ PUFAs per day) compared to placebo in pregnancy from 20 weeks of gestation until delivery [75].

Unbalanced PUFAs levels have been associated with FA. Children affected by FA showed a decrease of plasma content in $\omega-3$ PUFAs, and particularly EPA and DHA [22,69]. A recently published study showed that antenatal fish oil supplementation was associated with higher DHA and $\omega-3$ related metabolites at 1 year of age and, conversely, a higher $\omega-6$ PUFAs level was associated with higher odds of FA [80]. Instead, in a double-blind randomized controlled trial conducted in 420 infants at high atopic risk showed that daily fish oil supplementation (containing $280 \mathrm{mg}$ DHA and $110 \mathrm{mg}$ EPA) improved infant $\omega-3$ status (higher levels of DHA and EPA) compared to the control (olive oil), but did not prevent childhood allergic disease [78]. Another multicenter, randomized controlled trial performed on a large number of preterm infants $(n=657)$ breastfed from mothers taking either tuna oil (high-DHA diet, $\sim 1 \%$ total fatty acids) or soy oil (standard-DHA, $\sim 0.3 \%$ total fatty acids) capsules, showed no preventive effect on FA at 18 months of life [76]. Despite that, the study had the limitation that the incidence of FA was stated by parental reporting.

The $\omega-3$ PUFAs protective effect against FA in the offspring may further increase when supplementation is prolonged (e.g., extended during breastfeeding). Maternal supplementation with $2.7 \mathrm{~g} \omega-3$ PUFAs per day starting from week 25th of gestation until 3rd-4th month of breastfeeding in an at-risk population significantly lowered the FA prevalence in the offspring at 1 year of age [68]. Thus, it is clearly demonstrated that dosing, timing, and duration of maternal intervention contribute significantly to the FA preventive effect. In the same cohort of children, the $\omega-3$ PUFAs preventive effect was still measured at the age of 2 years, and new cases of FA were not prevented. Furthermore, high proportions of EPA and DHA in maternal and infant plasma were associated with the lowest chance of FA development and the severity of other allergies was reduced [77].

Furthermore, several lines of evidence have demonstrated associations between maternal lipidomic profiles and offspring FA risk. It was recently shown that a high content of long chain fatty acids and double bond numbers predominantly composed of PUFAs in maternal blood triacylglycerols was associated with up to a $40 \%$ risk reduction of FA in the offspring [81]. Maternal PUFAs, especially $\omega$-3 PUFAs, may regulate functions of the fetal immune system through several anti-inflammatory mechanisms and/or result in a reduced Th-2 response, thus protecting against FA [82-84]. 
In conclusion, the apparent absence of deleterious side effects of $\omega-3$ PUFAs treatments is neither a conclusive demonstration of their efficacy, nor a suggestion for an indiscriminate supplementation. It is necessary to intensify scientific efforts to clarify their actual effects to align medical and nutritional guidelines.

It should also be noted that all the above-mentioned trials focused on PUFAs supplementation in the form of oil or fish oil capsules, with standardized dosages.

By contrast, PUFAs intake through diet (mainly depending on fish consumption) has great variability among different regions and populations, and among people living in the same geographical area but with different dietary habits; this could explain the high variability in the trials' results.

\section{PUFAs Supplementation in Infancy and Childhood for Allergy Prevention}

The effect of $\omega-3$ PUFAs supplementation in infancy and childhood in preventing allergic diseases has also been investigated, and results are also conflicting. This could be due to a lack of standardization in population identification (high vs. low risk), underlying diet (breastfeeding vs. standard infant formula vs. free diet), baseline PUFAs serum levels and dose, timing and duration of supplementation [85].

Fish oil supplementation in infants and children resulted in higher $\omega-3$ PUFAs levels, but it is not clear whether these findings have clinical relevance [86].

While clinical intervention studies suggest a possible role of fish oil supplementation in infants/children in reducing wheezing and the need of bronchodilators, a meta-analysis [87] that included five relevant pediatric RCTs did not show significant reduction of asthma incidence with fish oil supplementation. This meta-analysis included a total of 2415 children receiving $\omega-3$ PUFAs dietary supplementation with fish oil capsules administered by mouth for an average of $0-12$ months and up to five years with an average duration of follow-up of 3-5 years, up to a maximum of 8 years. Among studies reported in the meta-analysis, the CAPS (Childhood Asthma Prevention Study) study interestingly showed in the active diet group receiving $\omega-3$ PUFAs supplementation an increase in $\omega-3 / \omega-6$ ratio at follow up, but this result did not match with any clinical effect or beneficial effect on lung function [88]. Conversely, Birch et al. [89] showed that term infants who had received PUFAs added to formula had a lower risk of wheezing, wheezing plus atopic dermatitis and any allergy at 3 years follow-up.

Foiles et al. [90] highlighted that infants receiving infant formula plus PUFAs for the first year of life had less allergic symptoms than those who received standard formula until 4 years old. PUFAs also lowered the prevalence of asthma in children at risk for atopy.

A double-blind randomized controlled trial by D'Vaz et al. [78] showed that $\omega-3$ fatty acids supplementation via fish oil from birth to six months of age in infants at high risk of allergy may have a protective role against wheeze and eczema, but no differences were reported in term of sensitization and FA at 6 months. At a 1 year follow up, no protective effect on clinical outcomes was noted [78].

Interestingly, an Iceland cohort study showed that $\omega-3$ PUFAs supplementation in infancy may decrease food sensitization and FA, although the latter was without statistical significance, and reduced severity of allergic symptoms [91].

The potential role of supplementation with PUFAs in FA children has not been investigated yet but could be of great interest to examine the immunomodulatory effect of $\omega-3$ PUFAs supplementation on the allergic phenotype.

\section{Conclusions}

$\omega-3$ PUFA may be particularly important for FA prevention and management. Discrepancies exist regarding the best timing and doses for $\omega-3$ PUFA supplementation for prevention purposes, and which individuals are most likely to benefit, also taking into account the role of genetic variation, which needs to be further investigated. These limitations make it difficult to draw firm conclusions. Furthermore, most clinical studies have focused only on FA prevention. More data on the effects of $\omega-3$ PUFA supplementation alone, or in 
combination with other nutrients with antioxidant and immunoregulatory properties, in FA patients are warranted.

Author Contributions: Conceptualization, M.U.A.S., E.D. and R.B.C.; writing-original draft preparation, M.U.A.S., E.P., S.C. and L.P.; writing-review and editing, E.P., E.D., R.B.C.; supervision, E.D., G.V.Z. and R.B.C. All authors have read and agreed to the published version of the manuscript.

Funding: This research received no external funding.

Conflicts of Interest: The authors declare no conflict of interest.

\section{References}

1. Hoppenbrouwers, T.; Cvejić Hogervorst, J.H.; Garssen, J.; Wichers, H.J.; Willemsen, L.E.M. Long Chain Polyunsaturated Fatty Acids (LCPUFAs) in the Prevention of Food Allergy. Front. Immunol. 2019, 10, 1118. [CrossRef] [PubMed]

2. Miles, E.A.; Calder, P.C. Can Early Omega-3 Fatty Acid Exposure Reduce Risk of Childhood Allergic Disease? Nutrients 2017, 9 , 784. [CrossRef] [PubMed]

3. Wendell, S.G.; Baffi, C.; Holguin, F. Fatty Acids, Inflammation, and Asthma. J. Allergy Clin. Immunol. 2014, 133, 1255-1264. [CrossRef] [PubMed]

4. Willemsen, L.E.M. Dietary N-3 Long Chain Polyunsaturated Fatty Acids in Allergy Prevention and Asthma Treatment. Eur. J. Pharmacol. 2016, 785, 174-186. [CrossRef]

5. Nagel, G.; Weinmayr, G.; Kleiner, A.; Garcia-Marcos, L.; Strachan, D.P. ISAAC Phase Two Study Group Effect of Diet on Asthma and Allergic Sensitisation in the International Study on Allergies and Asthma in Childhood (ISAAC) Phase Two. Thorax 2010, 65, 516-522. [CrossRef]

6. $\quad$ Ellwood, P.; Asher, M.I.; García-Marcos, L.; Williams, H.; Keil, U.; Robertson, C.; Nagel, G. ISAAC Phase III Study Group Do Fast Foods Cause Asthma, Rhinoconjunctivitis and Eczema? Global Findings from the International Study of Asthma and Allergies in Childhood (ISAAC) Phase Three. Thorax 2013, 68, 351-360. [CrossRef]

7. Barros, R.; Moreira, A.; Padrão, P.; Teixeira, V.H.; Carvalho, P.; Delgado, L.; Lopes, C.; Severo, M.; Moreira, P. Dietary Patterns and Asthma Prevalence, Incidence and Control. Clin. Exp. Allergy 2015, 45, 1673-1680. [CrossRef]

8. Spergel, J.M.; Paller, A.S. Atopic Dermatitis and the Atopic March. J. Allergy Clin. Immunol. 2003, 112, S118-S127. [CrossRef]

9. Spergel, J.M. Epidemiology of Atopic Dermatitis and Atopic March in Children. Immunol. Allergy Clin. North. Am. 2010, 30, 269-280. [CrossRef]

10. Lack, G. Epidemiologic Risks for Food Allergy. J. Allergy Clin. Immunol. 2008, 121, 1331-1336. [CrossRef]

11. Balić, A.; Vlašić, D.; Žužul, K.; Marinović, B.; Bukvić Mokos, Z. Omega-3 Versus Omega-6 Polyunsaturated Fatty Acids in the Prevention and Treatment of Inflammatory Skin Diseases. Int. J. Mol. Sci. 2020, 21, 741. [CrossRef]

12. U.S. Department of Agriculture. FoodData Central. Available online: https://fdc.nal.usda.gov/index.html (accessed on 11 November 2021).

13. Gnagnarella, P.; Salvini, S.; Parpinel, M. Food Composition Database for Epidemiological Studies in Italy, Version 1.2015. Available online: http:/ / www.bda-ieo.it/ (accessed on 11 November 2021).

14. Agostoni, C.; Nobile, M.; Ciappolino, V.; Delvecchio, G.; Tesei, A.; Turolo, S.; Crippa, A.; Mazzocchi, A.; Altamura, C.A.; Brambilla, P. The Role of Omega-3 Fatty Acids in Developmental Psychopathology: A Systematic Review on Early Psychosis, Autism, and ADHD. Int. J. Mol. Sci. 2017, 18, 2608. [CrossRef]

15. EFSA Panel on Dietetic Products, Nutrition, and Allergies (NDA). Scientific Opinion on Dietary Reference Values for Fats, Including Saturated Fatty Acids, Polyunsaturated Fatty Acids, Monounsaturated Fatty Acids, Trans Fatty Acids, and Cholesterol. EFSA J. 2010, 8, 1461. [CrossRef]

16. Sioen, I.; van Lieshout, L.; Eilander, A.; Fleith, M.; Lohner, S.; Szommer, A.; Petisca, C.; Eussen, S.; Forsyth, S.; Calder, P.C.; et al. Systematic Review on N-3 and N-6 Polyunsaturated Fatty Acid Intake in European Countries in Light of the Current Recommendations-Focus on Specific Population Groups. Ann. Nutr. Metab. 2017, 70, 39-50. [CrossRef]

17. Bahreynian, M.; Feizi, A.; Kelishadi, R. Is Fatty Acid Composition of Breast Milk Different in Various Populations? A Systematic Review and Meta-Analysis. Int. J. Food. Sci. Nutr. 2020, 71, 909-920. [CrossRef]

18. Koletzko, B.; Thiel, I.; Abiodun, P.O. The Fatty Acid Composition of Human Milk in Europe and Africa. J. Pediatr. 1992, 120, S62-S70. [CrossRef]

19. Brenna, J.T.; Varamini, B.; Jensen, R.G.; Diersen-Schade, D.A.; Boettcher, J.A.; Arterburn, L.M. Docosahexaenoic and Arachidonic Acid Concentrations in Human Breast Milk Worldwide. Am. J. Clin. Nutr. 2007, 85, 1457-1464. [CrossRef]

20. Halken, S.; Muraro, A.; de Silva, D.; Khaleva, E.; Angier, E.; Arasi, S.; Arshad, H.; Bahnson, H.T.; Beyer, K.; Boyle, R.; et al. EAACI Guideline: Preventing the Development of Food Allergy in Infants and Young Children (2020 Update). Pediatr. Allergy. Immunol. 2021, 32, 843-858. [CrossRef]

21. WHO. Maternal, Infant and Young Child Nutrition. 2016. EB138/8. Available online: https://apps.who.int/gb/e/e_eb138.html (accessed on 11 November 2021). 
22. Roduit, C.; Frei, R.; Depner, M.; Schaub, B.; Loss, G.; Genuneit, J.; Pfefferle, P.; Hyvärinen, A.; Karvonen, A.M.; Riedler, J.; et al. Increased Food Diversity in the First Year of Life Is Inversely Associated with Allergic Diseases. J. Allergy Clin. Immunol. 2014, 133, 1056-1064. [CrossRef]

23. Garcia-Larsen, V.; Ierodiakonou, D.; Jarrold, K.; Cunha, S.; Chivinge, J.; Robinson, Z.; Geoghegan, N.; Ruparelia, A.; Devani, P.; Trivella, M.; et al. Diet during Pregnancy and Infancy and Risk of Allergic or Autoimmune Disease: A Systematic Review and Meta-Analysis. PLoS Med. 2018, 15, e1002507. [CrossRef]

24. Venter, C.; Brown, K.R.; Maslin, K.; Palmer, D.J. Maternal Dietary Intake in Pregnancy and Lactation and Allergic Disease Outcomes in Offspring. Pediatr. Allergy Immunol. 2017, 28, 135-143. [CrossRef]

25. Greer, F.R.; Sicherer, S.H.; Burks, A.W.; Committee on Nutrition; Section on Allergy and Immunology. The Effects of Early Nutritional Interventions on the Development of Atopic Disease in Infants and Children: The Role of Maternal Dietary Restriction, Breastfeeding, Hydrolyzed Formulas, and Timing of Introduction of Allergenic Complementary Foods. Pediatrics 2019, 143, e20190281. [CrossRef]

26. D'Auria, E.; Pendezza, E.; Zuccotti, G.V. Personalized Nutrition in Food Allergy: Tips for Clinical Practice. Front Pediatr. 2020, 8, 113. [CrossRef]

27. Aldámiz-Echevarría, L.; Bilbao, A.; Andrade, F.; Elorz, J.; Prieto, J.A.; Rodríguez-Soriano, J. Fatty Acid Deficiency Profile in Children with Food Allergy Managed with Elimination Diets. Acta. Paediatr. 2008, 97, 1572-1576. [CrossRef]

28. Mourad, A.A.; Bahna, S.L. Fish-Allergic Patients May Be Able to Eat Fish. Expert Rev. Clin. Immunol. 2015, 11, 419-430. [CrossRef]

29. Giovannini, M.; D’Auria, E.; Caffarelli, C.; Verduci, E.; Barberi, S.; Indinnimeo, L.; Iacono, I.D.; Martelli, A.; Riva, E.; Bernardini, R. Nutritional Management and Follow up of Infants and Children with Food Allergy: Italian Society of Pediatric Nutrition/Italian Society of Pediatric Allergy and Immunology Task Force Position Statement. Ital. J. Pediatr. 2014, 40, 1. [CrossRef]

30. Skypala, I.J.; McKenzie, R. Nutritional Issues in Food Allergy. Clin. Rev. Allergy Immunol. 2019, 57, 166-178. [CrossRef]

31. Ogrodowczyk, A.M.; Zakrzewska, M.; Romaszko, E.; Wróblewska, B. Gestational Dysfunction-Driven Diets and Probiotic Supplementation Correlate with the Profile of Allergen-Specific Antibodies in the Serum of Allergy Sufferers. Nutrients 2020, 12, 2381. [CrossRef]

32. Gardner, K.G.; Gebretsadik, T.; Hartman, T.J.; Rosa, M.J.; Tylavsky, F.A.; Adgent, M.A.; Moore, P.E.; Kocak, M.; Bush, N.R.; Davis, R.L.; et al. Prenatal Omega-3 and Omega-6 Polyunsaturated Fatty Acids and Childhood Atopic Dermatitis. J. Allergy. Clin. Immunol. Pract. 2020, 8, 937-944. [CrossRef]

33. Berni Canani, R.; Paparo, L.; Nocerino, R.; Di Scala, C.; Della Gatta, G.; Maddalena, Y.; Buono, A.; Bruno, C.; Voto, L.; Ercolini, D. Gut Microbiome as Target for Innovative Strategies Against Food Allergy. Front Immunol. 2019, 10, 191. [CrossRef]

34. Van den Elsen, L.; Garssen, J.; Willemsen, L. Long Chain N-3 Polyunsaturated Fatty Acids in the Prevention of Allergic and Cardiovascular Disease. Curr. Pharm. Des. 2012, 18, 2375-2392. [CrossRef] [PubMed]

35. Bilal, S.; Haworth, O.; Wu, L.; Weylandt, K.H.; Levy, B.D.; Kang, J.X. Fat-1 Transgenic Mice with Elevated Omega-3 Fatty Acids Are Protected from Allergic Airway Responses. Biochim. Biophys. Acta 2011, 1812, 1164-1169. [CrossRef] [PubMed]

36. Morin, C.; Fortin, S.; Cantin, A.M.; Rousseau, E. Docosahexaenoic Acid Derivative Prevents Inflammation and Hyperreactivity in Lung: Implication of PKC-Potentiated Inhibitory Protein for Heterotrimeric Myosin Light Chain Phosphatase of 17 KD in Asthma. Am. J. Respir. Cell. Mol. Biol. 2011, 45, 366-375. [CrossRef] [PubMed]

37. Morin, C.; Fortin, S.; Cantin, A.M.; Rousseau, É. MAG-EPA Resolves Lung Inflammation in an Allergic Model of Asthma. Clin. Exp. Allergy 2013, 43, 1071-1082. [CrossRef]

38. Yokoyama, A.; Hamazaki, T.; Ohshita, A.; Kohno, N.; Sakai, K.; Zhao, G.D.; Katayama, H.; Hiwada, K. Effect of Aerosolized Docosahexaenoic Acid in a Mouse Model of Atopic Asthma. Int. Arch. Allergy Immunol. 2000, 123, 327-332. [CrossRef]

39. Hogenkamp, A.; van Vlies, N.; Fear, A.L.; van Esch, B.C.; Hofman, G.A.; Garssen, J.; Calder, P.C. Dietary Fatty Acids Affect the Immune System in Male Mice Sensitized to Ovalbumin or Vaccinated with Influenza. J. Nutr. 2011, 141, 698-702. [CrossRef]

40. van den Elsen, L.W.J.; Bol-Schoenmakers, M.; van Esch, B.C.A.M.; Hofman, G.A.; van de Heijning, B.J.M.; Pieters, R.H.; Smit, J.J.; Garssen, J.; Willemsen, L.E.M. DHA-Rich Tuna Oil Effectively Suppresses Allergic Symptoms in Mice Allergic to Whey or Peanut. J. Nutr. 2014, 144, 1970-1976. [CrossRef]

41. Van den Elsen, L.W.J.; Meulenbroek, L.A.P.M.; van Esch, B.C.A.M.; Hofman, G.A.; Boon, L.; Garssen, J.; Willemsen, L.E.M. CD25+ Regulatory T Cells Transfer N-3 Long Chain Polyunsaturated Fatty Acids-Induced Tolerance in Mice Allergic to Cow's Milk Protein. Allergy 2013, 68, 1562-1570. [CrossRef]

42. Mizota, T.; Fujita-Kambara, C.; Matsuya, N.; Hamasaki, S.; Fukudome, T.; Goto, H.; Nakane, S.; Kondo, T.; Matsuo, H. Effect of Dietary Fatty Acid Composition on Th1/Th2 Polarization in Lymphocytes. JPEN J. Parenter. Enteral. Nutr. 2009, 33, 390-396. [CrossRef]

43. Weise, C.; Hilt, K.; Milovanovic, M.; Ernst, D.; Rühl, R.; Worm, M. Inhibition of IgE Production by Docosahexaenoic Acid Is Mediated by Direct Interference with STAT6 and NFkB Pathway in Human B Cells. J. Nutr. Biochem. 2011, 22, 269-275. [CrossRef]

44. Draper, E.; Reynolds, C.M.; Canavan, M.; Mills, K.H.; Loscher, C.E.; Roche, H.M. Omega-3 Fatty Acids Attenuate Dendritic Cell Function via NF-KB Independent of PPAR $\gamma$. J. Nutr. Biochem. 2011, 22, 784-790. [CrossRef]

45. Zeyda, M.; Säemann, M.D.; Stuhlmeier, K.M.; Mascher, D.G.; Nowotny, P.N.; Zlabinger, G.J.; Waldhäusl, W.; Stulnig, T.M. Polyunsaturated Fatty Acids Block Dendritic Cell Activation and Function Independently of NF-KappaB Activation. J. Biol. Chem. 2005, 280, 14293-14301. [CrossRef] 
46. Kong, W.; Yen, J.-H.; Vassiliou, E.; Adhikary, S.; Toscano, M.G.; Ganea, D. Docosahexaenoic Acid Prevents Dendritic Cell Maturation and in Vitro and in Vivo Expression of the IL-12 Cytokine Family. Lipids. Health Dis. 2010, 9, 12. [CrossRef] [PubMed]

47. Prietl, B.; Treiber, G.; Pieber, T.R.; Amrein, K. Vitamin D and Immune Function. Nutrients 2013, 5, 2502-2521. [CrossRef]

48. Endo, J.; Arita, M. Cardioprotective Mechanism of Omega-3 Polyunsaturated Fatty Acids. J. Cardiol. 2016, 67, 22-27. [CrossRef]

49. Weatherill, A.R.; Lee, J.Y.; Zhao, L.; Lemay, D.G.; Youn, H.S.; Hwang, D.H. Saturated and Polyunsaturated Fatty Acids Reciprocally Modulate Dendritic Cell Functions Mediated through TLR4. J. Immunol. 2005, 174, 5390-5397. [CrossRef]

50. Hoppenbrouwers, T.; Fogliano, V.; Garssen, J.; Pellegrini, N.; Willemsen, L.E.M.; Wichers, H.J. Specific Polyunsaturated Fatty Acids Can Modulate in Vitro Human MoDC2s and Subsequent Th2 Cytokine Release. Front. Immunol. 2020, 11, 748. [CrossRef]

51. Adolph, S.; Fuhrmann, H.; Schumann, J. Unsaturated Fatty Acids Promote the Phagocytosis of P. Aeruginosa and R. Equi by RAW264.7 Macrophages. Curr. Microbiol. 2012, 65, 649-655. [CrossRef]

52. Ambrozova, G.; Pekarova, M.; Lojek, A. Effect of Polyunsaturated Fatty Acids on the Reactive Oxygen and Nitrogen Species Production by Raw 264.7 Macrophages. Eur. J. Nutr. 2010, 49, 133-139. [CrossRef] [PubMed]

53. Carlsson, J.A.; Wold, A.E.; Sandberg, A.-S.; Östman, S.M. The Polyunsaturated Fatty Acids Arachidonic Acid and Docosahexaenoic Acid Induce Mouse Dendritic Cells Maturation but Reduce T-Cell Responses In Vitro. PLoS ONE 2015, 10, e0143741. [CrossRef] [PubMed]

54. Fuhrmann, H.; Miles, E.A.; West, A.L.; Calder, P.C. Membrane Fatty Acids, Oxidative Burst and Phagocytosis after Enrichment of P388D1 Monocyte/Macrophages with Essential 18-Carbon Fatty Acids. Ann. Nutr. Metab. 2007, 51, 155-162. [CrossRef]

55. Schaeffer, L.; Gohlke, H.; Müller, M.; Heid, I.M.; Palmer, L.J.; Kompauer, I.; Demmelmair, H.; Illig, T.; Koletzko, B.; Heinrich, J. Common Genetic Variants of the FADS1 FADS2 Gene Cluster and Their Reconstructed Haplotypes Are Associated with the Fatty Acid Composition in Phospholipids. Hum. Mol. Genet. 2006, 15, 1745-1756. [CrossRef]

56. Moltó-Puigmartí, C.; Plat, J.; Mensink, R.P.; Müller, A.; Jansen, E.; Zeegers, M.P.; Thijs, C. FADS1 FADS2 Gene Variants Modify the Association between Fish Intake and the Docosahexaenoic Acid Proportions in Human Milk. Am. J. Clin. Nutr. 2010, 91, 1368-1376. [CrossRef]

57. Rzehak, P.; Heinrich, J.; Klopp, N.; Schaeffer, L.; Hoff, S.; Wolfram, G.; Illig, T.; Linseisen, J. Evidence for an Association between Genetic Variants of the Fatty Acid Desaturase 1 Fatty Acid Desaturase 2 ( FADS1 FADS2) Gene Cluster and the Fatty Acid Composition of Erythrocyte Membranes. Br. J. Nutr. 2009, 101, 20-26. [CrossRef]

58. Xie, L.; Innis, S.M. Genetic Variants of the FADS1 FADS2 Gene Cluster Are Associated with Altered (n-6) and (n-3) Essential Fatty Acids in Plasma and Erythrocyte Phospholipids in Women during Pregnancy and in Breast Milk during Lactation. J. Nutr. 2008, 138, 2222-2228. [CrossRef]

59. Tanaka, T.; Shen, J.; Abecasis, G.R.; Kisialiou, A.; Ordovas, J.M.; Guralnik, J.M.; Singleton, A.; Bandinelli, S.; Cherubini, A.; Arnett, D.; et al. Genome-Wide Association Study of Plasma Polyunsaturated Fatty Acids in the InCHIANTI Study. PLoS Genet. 2009, 5 , e1000338. [CrossRef]

60. Rzehak, P.; Thijs, C.; Standl, M.; Mommers, M.; Glaser, C.; Jansen, E.; Klopp, N.; Koppelman, G.H.; Singmann, P.; Postma, D.S.; et al. Variants of the FADS1 FADS2 Gene Cluster, Blood Levels of Polyunsaturated Fatty Acids and Eczema in Children within the First 2 Years of Life. PLoS ONE 2010, 5, e13261. [CrossRef]

61. Steer, C.D.; Hibbeln, J.R.; Golding, J.; Davey Smith, G. Polyunsaturated Fatty Acid Levels in Blood during Pregnancy, at Birth and at 7 Years: Their Associations with Two Common FADS2 Polymorphisms. Hum. Mol. Genet. 2012, 21, 1504-1512. [CrossRef]

62. Tintle, N.L.; Pottala, J.V.; Lacey, S.; Ramachandran, V.; Westra, J.; Rogers, A.; Clark, J.; Olthoff, B.; Larson, M.; Harris, W.; et al. A Genome-Wide Association Study of Saturated, Mono- and Polyunsaturated Red Blood Cell Fatty Acids in the Framingham Heart Offspring Study. Prostaglandins Leukot. Essent. Fatty Acids 2015, 94, 65-72. [CrossRef]

63. Demirkan, A.; van Duijn, C.M.; Ugocsai, P.; Isaacs, A.; Pramstaller, P.P.; Liebisch, G.; Wilson, J.F.; Johansson, Å.; Rudan, I.; Aulchenko, Y.S.; et al. Genome-Wide Association Study Identifies Novel Loci Associated with Circulating Phospho- and Sphingolipid Concentrations. PLoS Genet. 2012, 8, e1002490. [CrossRef]

64. Barman, M.; Nilsson, S.; Torinsson Naluai, Å.; Sandin, A.; Wold, A.E.; Sandberg, A.-S. Single Nucleotide Polymorphisms in the FADS Gene Cluster but Not the ELOVL2 Gene Are Associated with Serum Polyunsaturated Fatty Acid Composition and Development of Allergy (in a Swedish Birth Cohort). Nutrients 2015, 7, 10100-10115. [CrossRef] [PubMed]

65. Conway, M.C.; McSorley, E.M.; Mulhern, M.S.; Strain, J.J.; van Wijngaarden, E.; Yeates, A.J. Influence of Fatty Acid Desaturase (FADS) Genotype on Maternal and Child Polyunsaturated Fatty Acids (PUFA) Status and Child Health Outcomes: A Systematic Review. Nutr. Rev. 2020, 78, 627-646. [CrossRef] [PubMed]

66. Marques, A.H.; O'Connor, T.G.; Roth, C.; Susser, E.; Bjørke-Monsen, A.-L. The Influence of Maternal Prenatal and Early Childhood Nutrition and Maternal Prenatal Stress on Offspring Immune System Development and Neurodevelopmental Disorders. Front. Neurosci. 2013, 7, 120. [CrossRef] [PubMed]

67. Xu, P.; Wang, Z.; Li, J. Progress on the Protective Effects of Maternal Fatty Acid Supplementation on Infant Asthma Risk: A Narrative Review. Ann. Palliat. Med. 2021, 10, 2323-2330. [CrossRef]

68. Furuhjelm, C.; Warstedt, K.; Larsson, J.; Fredriksson, M.; Böttcher, M.F.; Fälth-Magnusson, K.; Duchén, K. Fish Oil Supplementation in Pregnancy and Lactation May Decrease the Risk of Infant Allergy. Acta. Paediatr. 2009, 98, 1461-1467. [CrossRef]

69. Palmer, D.J.; Sullivan, T.; Gold, M.S.; Prescott, S.L.; Heddle, R.; Gibson, R.A.; Makrides, M. Effect of N-3 Long Chain Polyunsaturated Fatty Acid Supplementation in Pregnancy on Infants' Allergies in First Year of Life: Randomised Controlled Trial. BMJ 2012, 344, e184. [CrossRef] 
70. Palmer, D.J.; Sullivan, T.; Gold, M.S.; Prescott, S.L.; Heddle, R.; Gibson, R.A.; Makrides, M. Randomized Controlled Trial of Fish Oil Supplementation in Pregnancy on Childhood Allergies. Allergy 2013, 68, 1370-1376. [CrossRef]

71. Gunaratne, A.W.; Makrides, M.; Collins, C.T. Maternal Prenatal and/or Postnatal n-3 Long Chain Polyunsaturated Fatty Acids (LCPUFA) Supplementation for Preventing Allergies in Early Childhood. Cochrane Database Syst. Rev. 2015, CD010085. [CrossRef]

72. Best, K.P.; Gold, M.; Kennedy, D.; Martin, J.; Makrides, M. Omega-3 Long-Chain PUFA Intake during Pregnancy and Allergic Disease Outcomes in the Offspring: A Systematic Review and Meta-Analysis of Observational Studies and Randomized Controlled Trials. Am. J. Clin. Nutr. 2016, 103, 128-143. [CrossRef]

73. Zhang, G.-Q.; Liu, B.; Li, J.; Luo, C.-Q.; Zhang, Q.; Chen, J.-L.; Sinha, A.; Li, Z.-Y. Fish Intake during Pregnancy or Infancy and Allergic Outcomes in Children: A Systematic Review and Meta-Analysis. Pediatr. Allergy. Immunol. 2017, 28, 152-161. [CrossRef]

74. Venter, C.; Agostoni, C.; Arshad, S.H.; Ben-Abdallah, M.; Du Toit, G.; Fleischer, D.M.; Greenhawt, M.; Glueck, D.H.; Groetch, M.; Lunjani, N.; et al. Dietary Factors during Pregnancy and Atopic Outcomes in Childhood: A Systematic Review from the European Academy of Allergy and Clinical Immunology. Pediatr. Allergy Immunol. 2020, 31, 889-912. [CrossRef]

75. Dunstan, J.A.; Mori, T.A.; Barden, A.; Beilin, L.J.; Taylor, A.L.; Holt, P.G.; Prescott, S.L. Fish Oil Supplementation in Pregnancy Modifies Neonatal Allergen-Specific Immune Responses and Clinical Outcomes in Infants at High Risk of Atopy: A Randomized, Controlled Trial. J. Allergy Clin. Immunol. 2003, 112, 1178-1184. [CrossRef]

76. Manley, B.J.; Makrides, M.; Collins, C.T.; McPhee, A.J.; Gibson, R.A.; Ryan, P.; Sullivan, T.R.; Davis, P.G.; DINO Steering Committee. High-Dose Docosahexaenoic Acid Supplementation of Preterm Infants: Respiratory and Allergy Outcomes. Pediatrics 2011, 128, e71-e77. [CrossRef]

77. Furuhjelm, C.; Warstedt, K.; Fagerås, M.; Fälth-Magnusson, K.; Larsson, J.; Fredriksson, M.; Duchén, K. Allergic Disease in Infants up to 2 Years of Age in Relation to Plasma Omega-3 Fatty Acids and Maternal Fish Oil Supplementation in Pregnancy and Lactation. Pediatr. Allergy Immunol. 2011, 22, 505-514. [CrossRef]

78. D’Vaz, N.; Meldrum, S.J.; Dunstan, J.A.; Martino, D.; McCarthy, S.; Metcalfe, J.; Tulic, M.K.; Mori, T.A.; Prescott, S.L. Postnatal Fish Oil Supplementation in High-Risk Infants to Prevent Allergy: Randomized Controlled Trial. Pediatrics 2012, 130, 674-682. [CrossRef]

79. Best, K.P.; Sullivan, T.R.; Palmer, D.J.; Gold, M.; Martin, J.; Kennedy, D.; Makrides, M. Prenatal Omega-3 LCPUFA and Symptoms of Allergic Disease and Sensitization throughout Early Childhood - a Longitudinal Analysis of Long-Term Follow-up of a Randomized Controlled Trial. World Allergy Organ J. 2018, 11, 10. [CrossRef]

80. Ellul, S.; Marx, W.; Collier, F.; Saffery, R.; Tang, M.; Burgner, D.; Carlin, J.; Vuillermin, P.; Ponsonby, A.-L.; Barwon Infant Study Investigator Group. Plasma Metabolomic Profiles Associated with Infant Food Allergy with Further Consideration of Other Early Life Factors. Prostaglandins Leukot. Essent. Fatty Acids 2020, 159, 102099. [CrossRef]

81. Hong, X.; Liang, L.; Sun, Q.; Keet, C.A.; Tsai, H.-J.; Ji, Y.; Wang, G.; Ji, H.; Clish, C.; Pearson, C.; et al. Maternal Triacylglycerol Signature and Risk of Food Allergy in Offspring. J. Allergy Clin. Immunol. 2019, 144, 729-737. [CrossRef]

82. Calder, P.C.; Kremmyda, L.-S.; Vlachava, M.; Noakes, P.S.; Miles, E.A. Is There a Role for Fatty Acids in Early Life Programming of the Immune System? Proc. Nutr. Soc. 2010, 69, 373-380. [CrossRef]

83. Prescott, S.L.; Dunstan, J.A. Prenatal Fatty Acid Status and Immune Development: The Pathways and the Evidence. Lipids 2007, 42, 801-810. [CrossRef]

84. Krauss-Etschmann, S.; Hartl, D.; Rzehak, P.; Heinrich, J.; Shadid, R.; Del Carmen Ramírez-Tortosa, M.; Campoy, C.; Pardillo, S.; Schendel, D.J.; Decsi, T.; et al. Decreased Cord Blood IL-4, IL-13, and CCR4 and Increased TGF-Beta Levels after Fish Oil Supplementation of Pregnant Women. J. Allergy Clin. Immunol. 2008, 121, 464-470.e6. [CrossRef]

85. D'Auria, E.; Peroni, D.G.; Sartorio, M.U.A.; Verduci, E.; Zuccotti, G.V.; Venter, C. The Role of Diet Diversity and Diet Indices on Allergy Outcomes. Front. Pediatr. 2020, 8, 545. [CrossRef]

86. Shek, L.P.; Chong, M.F.-F.; Lim, J.Y.; Soh, S.-E.; Chong, Y.-S. Role of Dietary Long-Chain Polyunsaturated Fatty Acids in Infant Allergies and Respiratory Diseases. Clin. Dev. Immunol. 2012, 2012, 730568. [CrossRef]

87. Muley, P.; Shah, M.; Muley, A. Omega-3 Fatty Acids Supplementation in Children to Prevent Asthma: Is It Worthy?-A Systematic Review and Meta-Analysis. J. Allergy 2015, 2015, 312052. [CrossRef]

88. Marks, G.B.; Mihrshahi, S.; Kemp, A.S.; Tovey, E.R.; Webb, K.; Almqvist, C.; Ampon, R.D.; Crisafulli, D.; Belousova, E.G.; Mellis, C.M.; et al. Prevention of Asthma during the First 5 Years of Life: A Randomized Controlled Trial. J. Allergy Clin. Immunol. 2006, 118, 53-61. [CrossRef]

89. Birch, E.E.; Khoury, J.C.; Berseth, C.L.; Castañeda, Y.S.; Couch, J.M.; Bean, J.; Tamer, R.; Harris, C.L.; Mitmesser, S.H.; Scalabrin, D.M. The Impact of Early Nutrition on Incidence of Allergic Manifestations and Common Respiratory Illnesses in Children. J. Pediatr. 2010, 156, 902-906.e1. [CrossRef]

90. Foiles, A.M.; Kerling, E.H.; Wick, J.A.; Scalabrin, D.M.F.; Colombo, J.; Carlson, S.E. Formula with Long-Chain Polyunsaturated Fatty Acids Reduces Incidence of Allergy in Early Childhood. Pediatr. Allergy Immunol. 2016, 27, 156-161. [CrossRef]

91. Clausen, M.; Jonasson, K.; Keil, T.; Beyer, K.; Sigurdardottir, S.T. Fish Oil in Infancy Protects against Food Allergy in Iceland-Results from a Birth Cohort Study. Allergy 2018, 73, 1305-1312. [CrossRef] 